\title{
ガス吹込みを伴う浴内のスクラップの 溶解促進に関するコールドモデル実験
}

\author{
井口 学*・新川 雅樹*2 ・森田 善一郎*3
}

Cold Model Experiments on the Enhancement of Scrap Melting in a Bath Accompanied by Gas Injection Manabu Iguchi, Masaki Shinkawa and Zen-ichiro Morita

Synopsis : A fundamental study based upon an aqueous system was carried out to reveal the effect of gas injection on the melting rate of solid bodies such as scrap. Ice spheres and ice cylinders were used as models of solid metals for the aqueous system. As the first step, the melting behavior of a single ice sphere or cylinder in a water bath was observed in this study using a high-speed video camera and by eye inspection. The melting rate of the ice was highly increased with an increase in gas flow rate. An estimation method of the melting time of the ice was proposed. Measured values of the melting time were found to compare well with estimated ones. The estimation method of the melting time originally proposed for the aqueous system was applicable to Wood's metal systems by adding time required for a solid Wood's metal sphere or cylinder to be heated up to its melting point.

Key words : scrap ; melting time ; cold model ; Nusselt number; sphere ; cylinder ; ice ; Wood's metal ; bubbling.

\section{1. 緒言}

ガス吹込みをはじめとするスクラップの溶解促進に関す る実験は以前から活発に行われており，溶解時間予測モデ ルも数多く提案されているが1) 8), 溶解挙動の予測に際して 最も重要なパラメーターである熱伝達率を通常ガス流量や 攪找動力密度の関数として与えており, 浴内の流動特性と 関連づけて評価した報告は非常に少ない2)3)。従来の熱伝達 率評価法は, 実際上非常に有用な方法ではあるが, 浴深や ガスの吹込み方法の相違によってフローパターンが異なれ ば適用できない可能性がある。

本研究では熱伝達率を攪挥動力密度ではなく, 浴内の平 均速度と乱れ強さの関数として評価し, 固体の溶解時間を 予測することを目的とする。すなわち，浴内に固定した固 体の熱伝達率に対して著者らが前に提案した実験式9110)を援 用して，まず浴内を自由に移動する単一の水球の溶解時間 を予測できるかぼうかを調べた。なお固体が球のように比 較的単純な外に凸の形状であれば，浴内を移動する間に表 面のいたるところが岐点(よどみ点)となる可能性が考えら れ，熱伝達は球の場合の值に近くなることが予想される。 そこで円柱形の水に対しても球の場合と同じ基礎式を用い て溶解時間を計算し, 測定値と比較して, この予測の妥当 性を検証した。さらに低融点のウッドメタルを用いて上記 水モデル実験と同様な実験を行っている宮部ら5の測定值と
の比較によって，ここで提案した溶解時間推定法の適用性 を調べた。

\section{2. 実験}

\section{$2 \cdot 1$ 水モデルによる溶解実験}

\section{$2 \cdot 1 \cdot 1$ 水の形状寸法が溶解時間に及ぼす影響}

実験装置の概要をFig. 1 に示す。浴は透明のアクリル樹脂 製で直径 $\mathrm{D}=20 \mathrm{~cm}$, 高さ $\mathrm{H}=36.5 \mathrm{~cm}$ の円筒形である。氷は 直径が $2.8 \mathrm{~cm}$ と $4.2 \mathrm{~cm}$ の球形, および $4.2 \mathrm{~cm}$ の球と表面積の

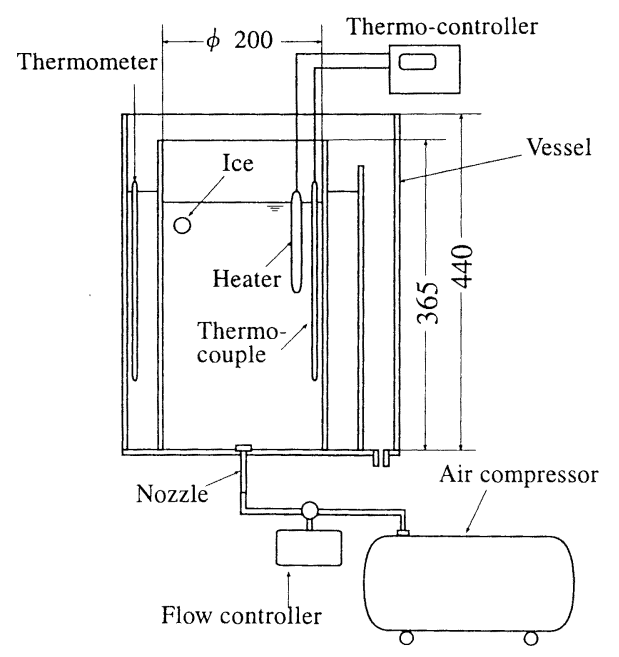

Fig. 1. Experimental apparatus for water model.

平成 6 年 7 月 27 H受付 平成 7 年 1 月 13 日受理 (Received on July 27, 1994; Accepted on Jan. 13, 1995)

* 大阪大学: I学部 (Faculty of Engineering, Osaka University, 2-1 Yamadaoka Suita 565)

* 2 大阪大学大学院生: (Graduate Student, Osaka University)

* 3 大阪大学工学部 (現：住友金属工業(株)) (Faculty of Engineering, Osaka University, now Sumitomo Metal Industries, Ltd.) 
等しい直径 $3.4 \mathrm{~cm}$, 高さ $3.5 \mathrm{~cm}$ の円柱形である。氷は $0{ }^{\circ} \mathrm{C}$ の 水水の中に保持して全体が $0{ }^{\circ} \mathrm{C}$ なるようにした後, 浴深 $\mathrm{H}_{\mathrm{L}}$ が $30 \mathrm{~cm}$ で，水温 $\mathrm{T}_{\mathrm{b}}$ が $12.5,25.0$ および $50.0^{\circ} \mathrm{C}$ の水浴中 に浴壁近傍から静かに投入し, 容器の底から内径 $2 \mathrm{~mm}$ の ズルを通して温度がそれぞれの水温に等しい空気を 10,20 ， $40,80,160 \mathrm{~cm}^{3} / \mathrm{s}$ の流量で吹き込んだ。

目視観察によって氷が融けてなくなるまでの時間を測定 し,これを溶解時間 $\mathrm{T}_{\mathrm{me}}$ とした。このとき, 各条件について 10回測定し，その平均をとった。溶解を行っている間に室 温との温度差によって水温が低下するのを防止するために， 円筒形の浴の周りを正方形断面の浴で囲い，その間に同じ 温度の水を満たした。

\section{$2 \cdot 1 \cdot 2$ 浴深が溶解に及ぼす影響}

Fig. 1 と同じ直径 $20 \mathrm{~cm}$ の浴と直径 $4.2 \mathrm{~cm}$ の球を用い, 水

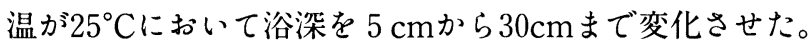
$2 \cdot 1 \cdot 3$ 浴径が溶解に及ぼす影響

直径Dが $20 \mathrm{~cm}$ の容器のほかに, $\mathrm{D}=12.2,39 \mathrm{~cm}$ の容器を 用いて直径と浴深との比 $\mathrm{H}_{\mathrm{L}} / \mathrm{D}$ を 1 に保ち, 水温が $25^{\circ} \mathrm{C} に$ いて直径 $2.8 \mathrm{~cm}$ と $4.2 \mathrm{~cm}$ の球を溶解した。

$2 \cdot 1 \cdot 4$ 溶解時間の推定法

水と水との間の熱収支の式を用いて溶解時間の計算を行 った。固定した球に対するヌッ七ルト数 $\mathrm{Nu}$ の実験式は次式 で与えられる11。

$$
\mathrm{Nu}=2+0.6 \mathrm{Re}^{(0.5+0.1 \mathrm{Tuv})} \operatorname{Pr}^{1 / 3}
$$

ここでReはレイノルズ数， $\mathrm{Tu}_{\mathrm{v}}$ は乱れ強さ，Prはプラント ル数であり，それぞれ次式で表される12)。

$$
\begin{aligned}
& \mathrm{Nu}=\mathrm{hd} / \lambda_{\mathrm{L}} \\
& \mathrm{Re}=\overline{\mathrm{V}}_{\mathrm{m}, \mathrm{v}} \mathrm{d} / \nu_{\mathrm{L}} \\
& \overline{\mathrm{V}}_{\mathrm{m}, \mathrm{v}}=39 \mathrm{Q}_{\mathrm{g}}{ }^{0.30} / \mathrm{D} \\
& \mathrm{Tu}_{\mathrm{v}}=0.98 \mathrm{Qg}^{0.06}
\end{aligned}
$$

ここで $\mathrm{h}$ ：熱伝達率， $\mathrm{d}$ ：球の直径, $\lambda_{\mathrm{L}}$ : 液体の熱伝導率, $\overline{\mathrm{V}}_{\mathrm{m}, \mathrm{v}}$ : 空間平均流速, $\nu_{\mathrm{L}}$ : 液体の動粘度であり, 添字 $\mathrm{v}$ は浴 内全体にわたって空間平均した值を表す。ただし式（4)，

（ 5 ）の成立範囲は $10 \mathrm{~cm}^{3} / \mathrm{s} \lesssim Q_{\mathrm{g}} \leqslant 160 \mathrm{~cm}^{3} / \mathrm{s}, 12.6 \mathrm{~cm} \lesssim \mathrm{D} \lesssim$ $30 \mathrm{~cm}, 0.5 \leqq \mathrm{H}_{\mathrm{L}} / \mathrm{D} \lesssim 1 て ゙ あ り$, 誤差は土 $15 \%$ と見積もられ ている。

球法浴内を自由に移動するため, 式（1）がそのまま適用 できるわけではないが，従来このような球の熱伝達に対す る式は報告されていないので，便宜的に式（1）を用いた。 したがって，溶解時間の測定值と計算值が合わない場合に は，適当な補正を施す。

さて, Fig. 2 に示すように固体(今の場合球)が溶解すると きには，次の熱収支が成立つ ${ }^{131414}$ 。

$$
-4 \pi \mathrm{r}^{2} \mathrm{dr} \cdot \rho_{\mathrm{s}} \Delta \mathrm{H}=4 \pi \mathrm{r}^{2} \mathrm{hdt} \cdot\left(\mathrm{T}_{\mathrm{b}}-\mathrm{T}_{\mathrm{o}}\right)
$$

ここで左辺は水の融解に要する熱量, 右辺は水から水へ熱

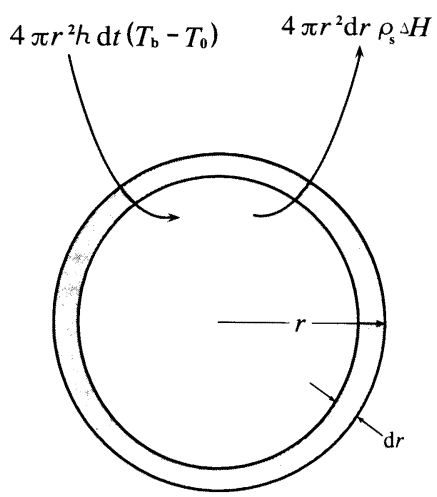

Fig. 2. Schematic of heat transfer between sphere and liquid.

伝達によって伝わる熱量であり, $\mathrm{r}$ は球の半径, $\rho_{\mathrm{s}}$ は水の密 度, $\Delta \mathrm{H}$ 冲水の融解熱, $\mathrm{t}$ は時間, $\mathrm{T}_{\mathrm{b}}$ はバルク層の水温, $\mathrm{T}_{\mathrm{o}}$ は氷の融点である。

式 (6) 整理すると次の微分方程式が得られる。

$\mathrm{dr} / \mathrm{dt}=-\mathrm{h}\left(\mathrm{T}_{\mathrm{b}}-\mathrm{T}_{\mathrm{o}}\right) /\left(\rho_{\mathrm{s}} \Delta \mathrm{H}\right)$

本実験では水の溶解に及ぼす温度差 $\left(\mathrm{T}_{\mathrm{b}}-\mathrm{T}_{\mathrm{o}}\right)$ の影響を単独 に評価できない。なぜならば，浴温が変ると動粘度やプラ ントル数が変化し，熱伝達率hも変るためである。

溶解時間の計算值 $\mathrm{T}_{\mathrm{me}, \mathrm{c}}$ は式 ( 7 ) に式 (1) を代入L, Simpsonの $1 / 3$ 公式を用いて数值積分法で求めた。

円柱形の水の溶解時間の推定は以下の方法にしたがって 行った。まず試料の表面積と等しい球を仮定し，その半径 をrとする。円柱で高さおよび半径方向に表面がともにdrだ け溶けたと仮定し，その減少した後の円柱の表面積に相当

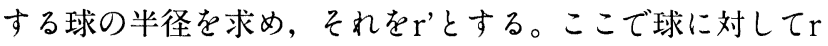
から $\mathrm{r}^{\prime}$ まで解けるのに要する時間を求める。以下同じ操作を

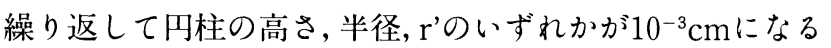
までの時間の和を溶解時間とした。

\section{$2 \cdot 2$ ウッドメタルを用いた溶解実験}

$2 \cdot 2 \cdot 1$ 実験装置 $飞$ 測定方法

ウッドメタルの溶解時間については宮部ら ${ }^{5}$ の測定值と本 推定法に基づく計算值との比較を行うが，ご了解を得て測 定法などの一部を再録させていただく。容器は転炉型であ り, ウッドメタルを溶解している部分の容器径は $\mathrm{D}=79.5 \mathrm{~cm}$, 浴深は $\mathrm{H}_{\mathrm{L}}=27.6 \mathrm{~cm}$ である。熱源および攪挥力は底吹きノズ ルからの窒素により可変にしている。

ウッドメタルの物性值は, 固体のときの密度 $\rho_{\mathrm{s}}=9200$ $\mathrm{kg} / \mathrm{m}^{3}$, 液体のときの密度 $\rho_{\mathrm{L}}=9590 \mathrm{~kg} / \mathrm{m}^{3}$, 比熱 $\mathrm{C}=0.04$ $\mathrm{kcal} / \mathrm{kg}^{\circ} \mathrm{C}$, 熱伝導率 $\lambda_{\mathrm{L}}=26 \mathrm{kcal} / \mathrm{mh}^{\circ} \mathrm{C}$, 融解熱 $\Delta \mathrm{H}=6.7$

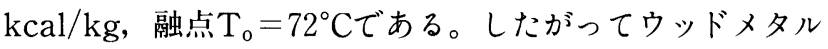
製の球や円柱はウッドメタル浴に投入されたとき，ちょう に゙水浴に投入された水のように浮く。これはウッドメタル 中にビスマスが入っていることによる。

球の直径は $7.0 \mathrm{~cm}$ と $13.0 \mathrm{~cm}$ の 2 種類, 円柱は直径 $7.0 \mathrm{~cm}$, 長さ $17.5 \mathrm{~cm}$ と直径 $5.0 \mathrm{~cm}$, 長さ $12.5 \mathrm{~cm}$ の 2 種類である。 


\section{$2 \cdot 2 \cdot 2$ 溶解時間の推定法}

乱れ強さの小さい溶融金属の一様流中におかれた球の又 ッセルト数に対する実験式はいくつか提案されているが15) 17), 熱伝達の測定が非常に難しいことから，信頼性の高い実験 式は見当たらない。しかし水や空気中におかれた球と無限 円柱のヌッセルト数の実験式の関数形は非常によく似てお り，しかもヌッセルト数そのものの值もたかだか数\%の差 でしかない。このことは溶融金属についても成立すると考 えられるので，本論文では無限円柱に対して著名な次の実 験式を採用し，球の場合にも適用した17)。

$$
\mathrm{Nu}=1.125(\operatorname{RePr})^{0.413}
$$

式（８）の妥当性を検証するために，著者らがウッドメタ ル浴内で支持棒の先に取り付けたウッドメタル球を旋回さ せたときの溶解速度から求めたヌッセルト数の測定值なら

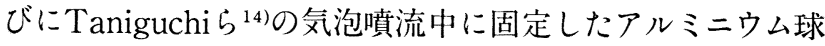
のヌッセルト数の測定値と比較してFig. 3 に示す。式 (8) 各測定値との一致は良好である。なお，本実験装置の詳細 は文献 ${ }^{18)}$ を参照されたい。データ整理法は文献 ${ }^{14)}$ と同じであ る。

式（８）では乱れ強さを考慮していないが，以下溶融金属 中における固体からの熱伝達に対する乱れの寄与について 考察する。

水中に浸漬した球の周りの速度境界層 $と$ 温度境界層の厚 さは, 本実験範囲の水のプラントル数が約 6 であることか ら，速度境界層の方がやや厚い。したがって，乱れによっ て速度境界層が影響を受けてその厚さが時々刻々変化すれ ば，温度境界層も影響を受けてその厚さが变化し，熱伝達 率が変る。一方, 溶融金属のプラントル数は $1 / 100$ のオーダ 一であり, 温度境界層は速度境界層よりも非常に厚く, 速 度境界層の厚さが時間的に変化しても, 温度境界層の厚さ はその影響を受けることなく，熱伝達率は平均流のみに規 定されると考えてよいであろう。Fig. 3 中のTaniguchiらの

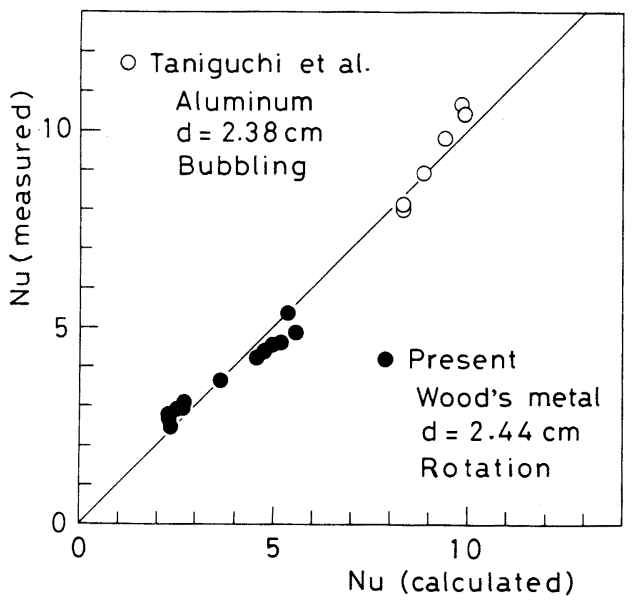

Fig. 3. Comparison between measured and calculated values of Nusselt number for metal sphere.
測定値は，乱れ強さが $40 ５ 0 \%$ の気泡噴流中で得られたに もかかわらず，式（８）によく一致していることはこの予測 の妥当性を物語っている。

以上の考察により，本論文では式（８）をそのまま用いる ことにする。式（８）を式（7）に代入して整理すれば，水の 場合と異なり容易に積分できて, 溶解時間 $\mathrm{T}_{\mathrm{me}, \mathrm{c}}$ は次式で与 えられる。

$$
\begin{array}{r}
\mathrm{T}_{\mathrm{me}, \mathrm{c}}=2 \mathrm{R}_{\mathrm{o}}{ }^{2} \rho_{\mathrm{S}} \Delta \mathrm{H} /\left(1.587 \mathrm{Nu}_{\mathrm{o}} \lambda_{\mathrm{L}} \Delta \mathrm{T}\right) \\
\quad=1080 \mathrm{R}_{\mathrm{o}}{ }^{2} /\left(\mathrm{Nu}_{0} \Delta \mathrm{T}\right) \ldots \ldots \ldots \ldots \ldots \ldots \ldots \ldots \ldots \ldots \ldots
\end{array}
$$

ここでR $\mathrm{R}_{\mathrm{o}}$ は球の初期半径, $\mathrm{Nu}_{\mathrm{o}}=1.125\left(\mathrm{Re}_{\mathrm{o}} \mathrm{Pr}\right)^{0.413}, \mathrm{Re}_{\mathrm{o}}=$ $2 \mathrm{R}_{\mathrm{o}} \overline{\mathrm{V}}_{\mathrm{m}, \mathrm{v}} / \nu_{\mathrm{L}}, \Delta \mathrm{T}=\mathrm{T}_{\mathrm{b}}-\mathrm{T}_{\mathrm{o}}$ である。円柱の場合には端面の 寄与があるので水モデルと同様な計算を行った。

レイノルズ数Reの計算に必要な空間平均流速 $\overline{\mathrm{V}}_{\mathrm{m}, \mathrm{v}}$ には水 の場合の式（4）をそのまま用いた。これは次の理由による。 気泡噴流部では, ノズル近傍を除き, 気泡の浮力が流れ場 を支配すると考えてよい。このとき気泡の浮力と流動抵抗 とが釣り合っており，次式が成立する。

$$
\left(\rho_{\mathrm{L}}-\rho_{\mathrm{g}}\right) \mathrm{g} \pi \overline{\mathrm{d}}_{\mathrm{B}}{ }^{3} / 6=\mathrm{C}_{\mathrm{D}}\left(\pi \overline{\mathrm{d}}_{\mathrm{B}}{ }^{2} / 4\right) \rho_{\mathrm{L}}\left(\overline{\mathrm{u}}_{\mathrm{B}}-\overline{\mathrm{u}}_{\mathrm{L}}\right)^{2} / 2
$$

ここで $\rho_{\mathrm{L}} \varepsilon \rho_{\mathrm{g}}$ は液体とガスの密度, $\mathrm{g}$ は重力加速度, $\overline{\mathrm{d}}_{\mathrm{B}}$ は平 均気泡径, $\mathrm{C}_{\mathrm{D}}$ は抵抗係数, $\overline{\mathrm{u}}_{\mathrm{B}} \varepsilon \overline{\mathrm{u}}_{\mathrm{L}}$ は気泡 $と$ 液体の平均上昇 速度である。

乱流の場合， $\mathrm{C}_{\mathrm{D}}$ はほぼ一定とみなすことができ，また $\rho_{\mathrm{L}}$ $》 \rho_{g}$ であるから気液の上昇速度の差すなわち滑り速度 $\bar{u}_{\mathrm{s}}=$ $\overline{\mathrm{u}}_{\mathrm{B}}-\overline{\mathrm{u}}_{\mathrm{L}}$ は次式で近似できる。

$$
\overline{\mathrm{u}}_{\mathrm{B}}-\overline{\mathrm{u}}_{\mathrm{L}}=\left[4 \mathrm{~g} \overline{\mathrm{d}}_{\mathrm{B}} /\left(3 \mathrm{C}_{\mathrm{D}}\right)\right]^{1 / 2}
$$

ノズルで生成される気泡直径 $\bar{B}_{B}$ は次式で与えられる19。

$$
\overline{\mathrm{d}}_{\mathrm{B}}=0.274\left(\sigma / \rho_{\mathrm{L}}\right)^{1 / 12}\left(\rho_{\mathrm{L}} / \rho_{\mathrm{g}}\right)^{1 / 15} \mathrm{Q}_{\mathrm{g}}{ }^{4 / 15} \mathrm{~d}_{\mathrm{n} 1}{ }^{1 / 6}
$$

ここで $\mathrm{d}_{\mathrm{n} 1}$ はノズル内径を表す。

式(12)を式(11)に代入して整理すれば

$$
\begin{aligned}
& \overline{\mathrm{u}}_{\mathrm{B}}-\overline{\mathrm{u}}_{\mathrm{L}}=18.9 \mathrm{C}_{\mathrm{D}}{ }^{-1 / 2}\left(\sigma / \rho_{\mathrm{L}}\right)^{1 / 24}\left(\rho_{\mathrm{L}} / \rho_{\mathrm{g}}\right)^{1 / 30} \\
& \times \mathrm{Q}_{\mathrm{g}}{ }^{2 / 15} \mathrm{~d}_{\mathrm{ni}}{ }^{1 / 12}
\end{aligned}
$$

となるが, 液体と気体の物性值に依存する $\left(\sigma / \rho_{\mathrm{L}}\right)^{1 / 24}\left(\rho_{\mathrm{L}} /\right.$ $\left.\rho_{\mathrm{g}}\right)^{1 / 30}$ の值は水一空気系に対し 1.5 , ウッドメタル一窒素系 に対しては1.59となり，たかだか $6 \%$ の相違でしかない。 したがって,両システムの滑り速度 $\overline{\mathrm{u}}_{\mathrm{B}}-\overline{\mathrm{u}}_{\mathrm{L}}$ はほぼ一致する。 さらに浮力の支配的な領域の平均気泡上昇速度 $\overline{\mathrm{u}}_{\mathrm{B}}$ は液体 と気体の物性值に依存せず次式 ${ }^{20)}$

$$
\overline{\mathrm{u}}_{\mathrm{B}}=1.7\left(\mathrm{Q}_{\mathrm{g}} \mathrm{g}^{2}\right)^{1 / 5}
$$

で与えられる。したがって，式(13)，(14)から $\overline{\mathrm{u}}_{\mathrm{L}}$ 恃水一空 気系とウッドメタルー窒素系でほとんぞ差がない。空間平 均流速 $\overline{\mathrm{V}}_{\mathrm{m}, \mathrm{v}}$ は $\overline{\mathrm{u}}_{\mathrm{L}}$ に直接関係しているので， $\overline{\mathrm{V}}_{\mathrm{m}, \mathrm{v}}$ に水一空気 系の式 $(4)$ をそのまま採用した。 $\mathrm{T}_{\mathrm{uv}} に$ に関しても同様な考え 
に基づき，式（ 5 ）を用いた。

ウッドメタルは融点の $72^{\circ} \mathrm{C}$ りも低い温度で浴内に投入 されるために，上記計算結果にウッドメタルが融点に達す るまでの時間 $\mathrm{T}_{\mathrm{wu}}$ を加える必要がある。この時間を正確に評 価することは難しいので，ここでは便宜的にハイスラー線 困を用いて計算する ${ }^{21)}$ 。本実験条件下の球に対してはビオ数 $\mathrm{Bi}=\mathrm{hR}_{\mathrm{o}} / \lambda_{\mathrm{s}}$ の逆数が約 0.05 となるので, 球中心の温度が融 点の $95 \%$ になったとき溶解が始まると仮定すれば，フーリ 工数 $\mathrm{F}_{\mathrm{O}}$ は 0.4 となり， $\mathrm{T}_{\mathrm{wu}}$ は次式で計算できる。

$\mathrm{T}_{\mathrm{wu}}=0.4 \mathrm{R}_{\mathrm{o}}^{2} / \varkappa_{\mathrm{L}}$

$\mathrm{F}_{0}$ の評価には任意性が伴うが，球中心の温度を融点の99 \%にしても式(20)の係数が0.6になるだけでありこの差は $\mathrm{T}_{\mathrm{me,c}}$ に対して約 $10 \%$ 以下の影響を及ぼすにすぎない。

\section{3. 結果と考察}

\section{$3 \cdot 1$ 水モデル実験}

$3 \cdot 1 \cdot 1$ 溶解時間に及ぼす沓の形状寸法の影響

Fig. 4, 5 は球形の水, Fig. 6 は円柱形の水の溶解時間を

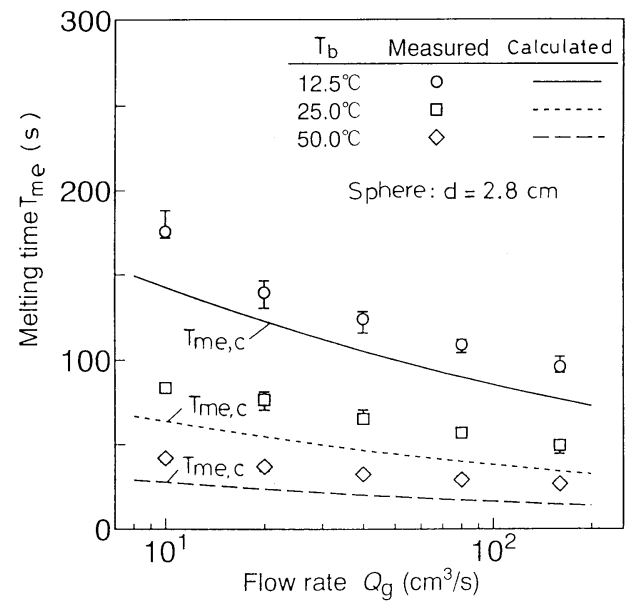

Fig. 4. Effect of gas flow rate on melting time (sphere: $\mathrm{d}=2.8 \mathrm{~cm}$ ).

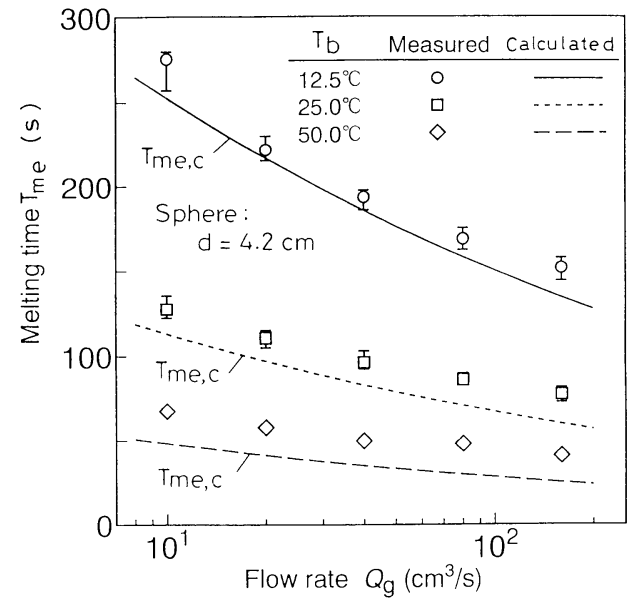

Fig. 5. Effect of gas flow rate on melting time (sphere : $\mathrm{d}=4.2 \mathrm{~cm}$ )

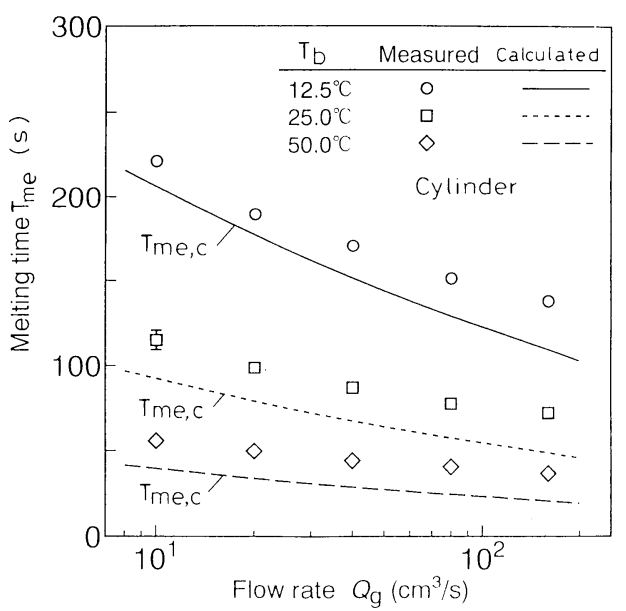

Fig. 6. Effect of gas flow rate on melting time (cylinder).

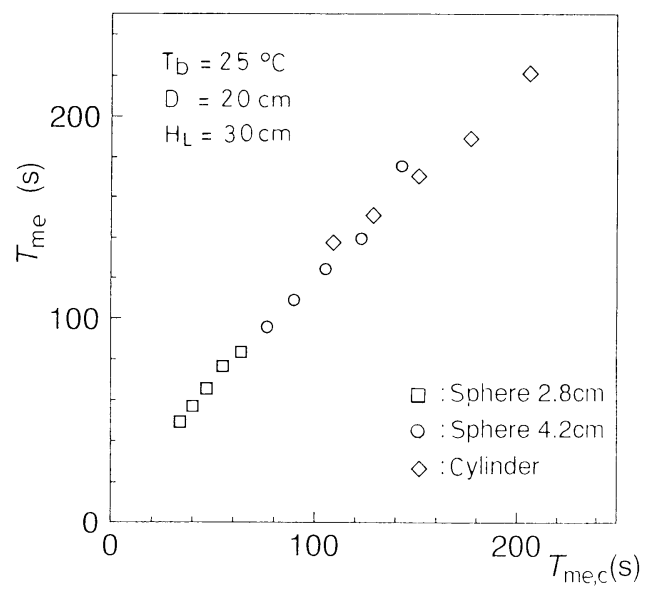

Fig. 7. Comparison between measured and calculated values of melting time for $T_{b}=25^{\circ} \mathrm{C}$, $\mathrm{D}=20 \mathrm{~cm}, \mathrm{H}_{\mathrm{L}}=30 \mathrm{~cm}$

ガス流量に対して示している。いずれの网でも計算值は測 定值よりやや小さくなっている。これは, 水が自由に動け るので液体との相対速度が計算に用いた值より小さくなっ ているためである。

Fig. 7 に浴温 $25^{\circ} \mathrm{C}$ におり 3 種類の水の溶解時間を示し た。氷の大きさや形状が異なっても溶解時間の測定值 $T_{\mathrm{me}}$ と 計算値 $\mathrm{T}_{\mathrm{me}, \mathrm{c}}$ との間には強い相関がある。

$3 ・ 1 ・ 2$ 溶解時間に及ぼす浴深の影響

Fig. 8 には, 浴深 $\mathrm{H}_{\mathrm{L}}$ を $5 \mathrm{~cm}$ から $30 \mathrm{~cm}$ まで変化させたとき の溶解時間をガス流量に対して示した。浴深が $10 \mathrm{~cm}$ 以下の 場合，浴が浅すぎるためにガスが液体に十分にエネルギー を伝えないうちに浴表面から出ており, $\overline{\mathrm{V}}_{\mathrm{m}, \mathrm{v}}$ と $\mathrm{Tu}_{\mathrm{v}}$ が式(4), (5)の值に比べて小さくなって, 溶解時間が計算值よりも 長くなったと考えられる。浴深が $15 \mathrm{~cm}$ 以トの場合, 溶解時 間は浴深に依存しない。

$3 ・ 1 ・ 3$ 溶解時間に及ぼす浴径の影響

容器径Dによる溶解時間 $\mathrm{T}_{\mathrm{me}}$ の変化をFig. 9 , 10に示す。 吹き込まれたガス流量が等しいとき，直径の小さい容器の ほうが $\overline{\mathrm{V}}_{\mathrm{m}, \mathrm{v}}$ が大きくなり，溶解時間は短くなる。 


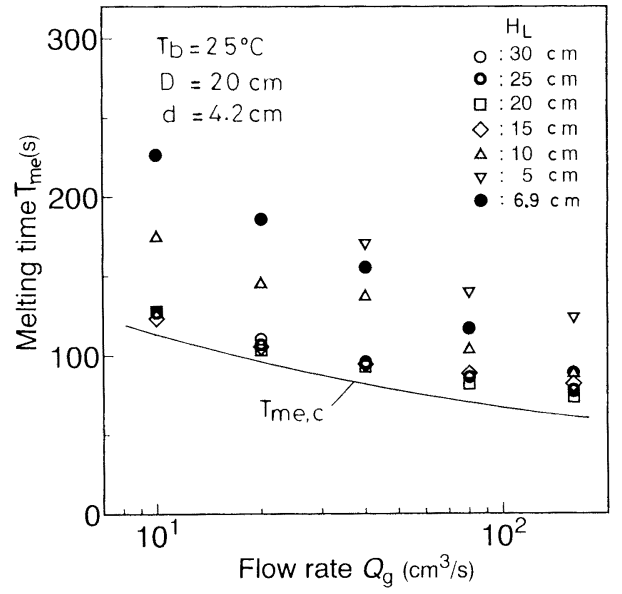

Fig. 8. Effect of bath depth on melting time (sphere : $\mathrm{d}=4.2 \mathrm{~cm}$ ).

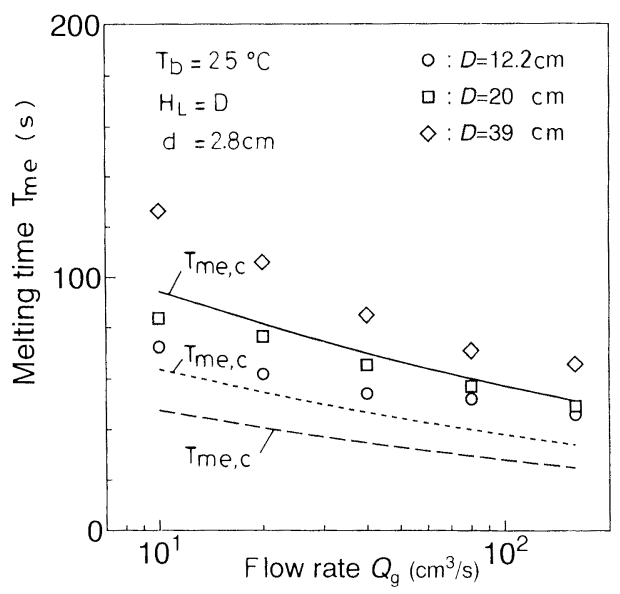

Fig. 9. Effect of vessel diameter on melting time (sphere: $\mathrm{d}=2.8 \mathrm{~cm}$ ).

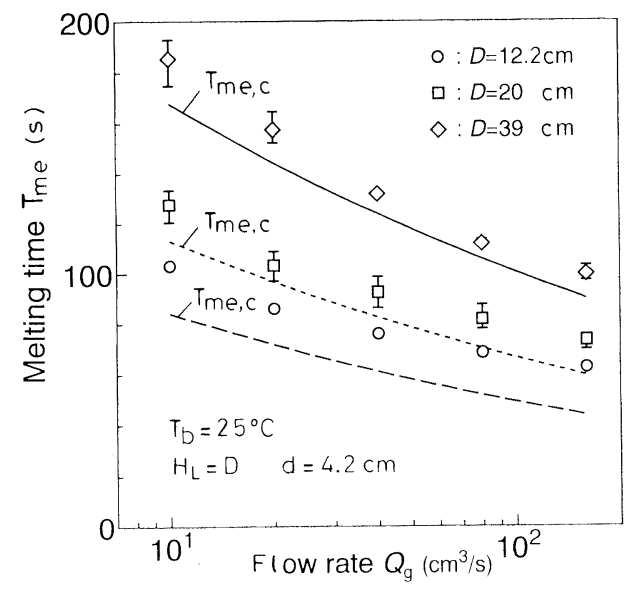

Fig. 10. Effect of vessel diameter on melting time (sphere : $\mathrm{d}=4.2 \mathrm{~cm}$ ).

$3 \cdot 1 \cdot 4$ 测定值と計算傎との比較

浴深が十分大きく吹き抜けや旋回が起こらない場合につ いて, 溶解時間のすべての測定值と計算值とを比較してFig. 11に示す。ただし汹中の記号の詳細はTable 1 に掲げてある。 今回の実験条件ドでは, 浴解時間 $\mathrm{T}_{\mathrm{me}}$ は次式によって $10 \%$ の偏差で近似できる。

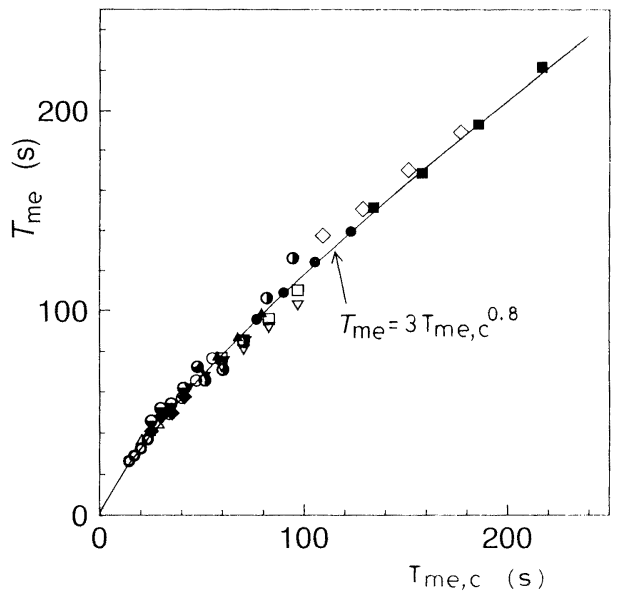

Fig. 11. Comparison between measured and calculated values of melting time for deep baths.

Table 1. Symbols in Fig.11.

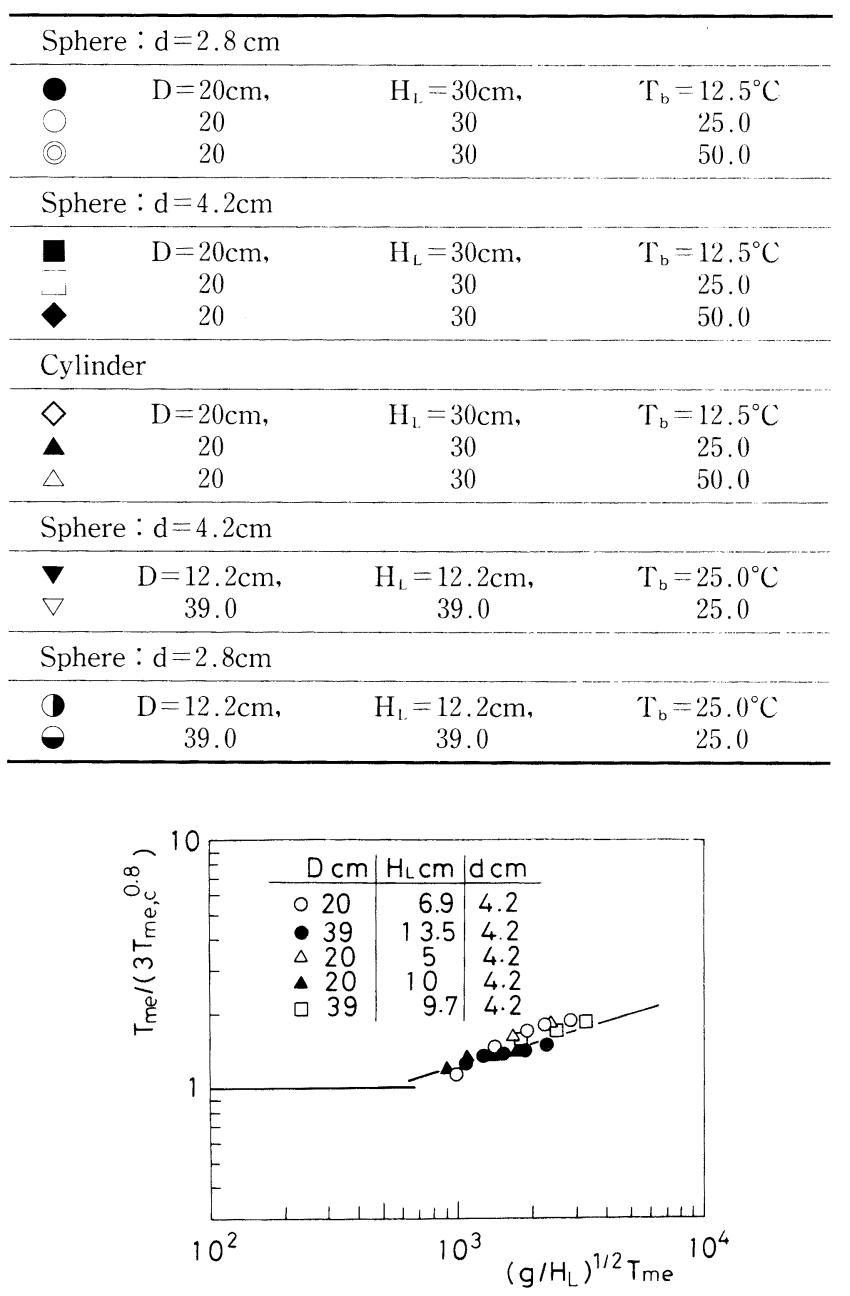

Fig. 12. Correlation of melting time for shallow baths (sphere : $\mathrm{d}=4.2 \mathrm{~cm}$ ).

$$
\mathrm{T}_{\mathrm{me}}=3 \mathrm{~T}_{\mathrm{me}, \mathrm{c}}{ }^{0.8}
$$

$3 \cdot 1 \cdot 5$ 浴が浅い場合の実験式の導出

Fig.12に浴が浅い場合の溶解時間の測定值を式(16)の右辽 で除した值を $\left(\mathrm{g} / \mathrm{H}_{\mathrm{L}}\right)^{1 / 2} \mathrm{~T}_{\mathrm{me}}$ に対して示した。ここで $\left(\mathrm{g} / \mathrm{H}_{\mathrm{L}}\right)^{1 / 2}$ 
による $\mathrm{T}_{\mathrm{me}}$ の無次元化は重力波の伝播速度を参考にして導い た。Fig.12の測定值は図中に示した次式で比較的よく整理で きる。

$$
\mathrm{T}_{\mathrm{me}} /\left(3 \mathrm{~T}_{\mathrm{me}, \mathrm{c}}{ }^{0.8}\right)=0.166\left[\left(\mathrm{~g} / \mathrm{H}_{\mathrm{L}}\right)^{1 / 2} \mathrm{~T}_{\mathrm{me}}\right]^{0.29}
$$

この式から $\mathrm{T}_{\mathrm{me}}$ を求め,さらに若干の整理を施すことによっ て次の実験式を導出した。

$$
\begin{aligned}
& \mathrm{T}_{\mathrm{me}}=0.38\left(\mathrm{~g} / \mathrm{H}_{\mathrm{L}}\right)^{0.20} \mathrm{~T}_{\mathrm{me}, \mathrm{c}}{ }^{1.12} \\
& \quad\left[800>\left(\mathrm{g} / \mathrm{H}_{\mathrm{L}}\right)^{1 / 2} \mathrm{~T}_{\mathrm{me}, \mathrm{c}}{ }^{0.8} \geqq 300\right] \\
& \mathrm{T}_{\mathrm{me}}=3 \mathrm{~T}_{\mathrm{me}, \mathrm{c}}{ }^{0.8} \\
& \quad\left[40<\left(\mathrm{g} / \mathrm{H}_{\mathrm{L}}\right)^{1 / 2} \mathrm{~T}_{\mathrm{me}, \mathrm{c}}{ }^{0.8}<300\right]
\end{aligned}
$$

ただし $\mathrm{T}_{\mathrm{me,c}}$ は第 2 章で求めた計算值である。式 (18)，(19) は測定值を $\pm 20 \%$ の偏差で近似できる。

\section{$3 ・ 2$ ウッドメタルの溶解実験結果との比較}

Fig.13に球と円柱に対するすべての溶解時間の測定值を計 算值と比較して示す。計算值は水モデルの結果を援用した 次式で求めた。

$$
\begin{aligned}
& \mathrm{T}_{\mathrm{me}}=0.38\left(\mathrm{~g} / \mathrm{H}_{\mathrm{L}}\right)^{0.20} \mathrm{~T}_{\mathrm{me}, \mathrm{c}}{ }^{1.12}+\mathrm{T}_{\mathrm{wu}} \\
& {\left[800>\left(\mathrm{g} / \mathrm{H}_{\mathrm{L}}\right)^{1 / 2} \mathrm{~T}_{\mathrm{me}, \mathrm{c}}{ }^{0.8} \geqq 300\right]} \\
& \mathrm{T}_{\mathrm{me}}=3 \mathrm{~T}_{\mathrm{me}, \mathrm{c}}{ }^{0.8}+\mathrm{T}_{\mathrm{wu}} \\
& {\left[40<\left(\mathrm{g} / \mathrm{H}_{\mathrm{L}}\right)^{1 / 2} \mathrm{~T}_{\mathrm{me}, \mathrm{c}}{ }^{0.8}<300\right] \cdots \cdots . . .}
\end{aligned}
$$

測定値は本推算法により土40\%の偏差で近似でき,式 (20), (21)がおおむね妥当であることが実証された。

より実操業条件に近いホットモデルのガス吹込み浴内に おける固体の溶解に対する本推算法の妥当性については今

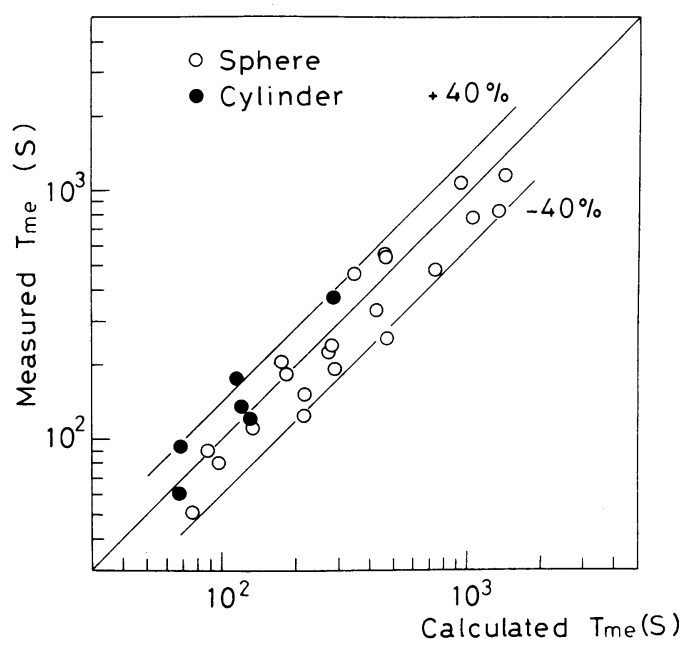

Fig. 13. Comparison between measured values of melting time by Miyabe et al. and calculated values from Eqs. (20) and (21).
後の課題としたい。

\section{4. 結言}

まず水モデルを用いて，浴内に投入された単一スクラッ プの溶解時間に及ぼすスクラップの形状と寸法, 吹込みガ ス流量, 浴深, 容器径などの影響を調べ, 式 (18)，（19）を 導出した。これらの式は測定值を $\pm 20 \%$ の偏差で近似でき る。また式 (18)，（19）にウッドメタルが浴内に投入されて から融点に達するまでの時間を加えた式 (20)，（21）によっ て, ウッドメタルの溶解時間の测定值も $\pm 40 \%$ の偏差で近 似できる。

新日本製鉄 (株)，室蘭製鉄所の工藤一郎博士にはウッド メタルの溶解実験に関して多くのご教示を頂いた。ここに 記して感謝の意を表する。

\section{文献}

1) H.Gaye, M.Wanin, P.Gugliermina and Ph.Schittly: Proc. 68th Steelmaking Conf., AIME (1985), p.91

2 ) 磯部浩一, 河内雄二, 前出弘文, 奥野嘉雄: 材料とプロセス, 2 (1989), p.1084

3 ) 磯部浩一, 前出弘文, 奥野嘉雄：材料とプロセス, 3 (1990), p.130

4 ）磯部浩一, 前出弘文, 奥野嘉雄, 小沢浩作, 梅沢一誠, 斎藤 力: 材料とプロセス, 3 (1990), p.1139

5 ）宮部修一，工藤一郎，矢崎 尚，磯部浩一：材料とプロセス，3 (1990), p.1140

6 ）錦織正規，石塚晴彦，野村 寞，朝穂隆一：材料とプロセス，4 (1991), p.1298

7 ) 田中 勉, 工藤一郎, 宮部修一, 矢崎 尚, 田中重雄, 石井博美 : 材料とプロセス， 4 (1991), p.1299

8 ) M.Kawakami, T.Hiroe and K.Mitati : Proc. 6th Japan-China Symp. (1992), p.225；広江俊勝, 川上正博, 三田地紘史：材料 $\varepsilon$ プロセス, 5 (1992), p.15

9 ）井口 学, 谷 潤一, 植村知正：鉄 と 鋼, 74 (1988), p.2106

10）井口 学, 竹内博明, 川端弘俊, 植村知正, 森旧善一郎：鉄 2 鋼, 75 (1989), p.2031

11）井口 学, 富田祐志, 中島敬治, 森田善一郎：鉄 $飞$ 鋼, 78 (1992), p.1786

12）井口 学，新川雅樹，中村英世，森田善一郎：鉄 $と$ 鋼，81 (1995), p.105，あるいは井口 学, 森田善一郎, 中村英世：製鋼第19委員 会鋼中非金属介在物小委員会, 介在物, 流動4-17, 流動グループ 研究発表会提出資料

13) S.Taniguchi, M.Ohmi, S.Ishiura and T.Yamauchi : Trans. ISIJ, 23 (1983), p.565

14) S.Taniguchi, M.Ohmi and S.Ishiura : Trans. ISIJ, 23 (1983), p.571

15) J.P.Holman : Heat transfer, 3rd ed., (1972), p.198 [McGrawHill Kogakusha

16）伝熱工学資料（日本機械学会編），改訂第3版，(1980)，p.74

17）伝熱工学資料（日本機械学会編）, 改訂第4版, (1986), p.109

18) M.Iguchi, M.Takeuchi, H.Kawabata, K.Ebina and Z.Morita : Trans. JIM, 35 (1994), p.720

19）井口 学, 高梨智裕, 小川雄二, 徳光直樹, 森田善一郎：鉄 鋼, 80 (1994), p.515

20）井口 学, 野沢健太郎, 富田祐志, 森田善一郎：鉄と鋼, 77 (1991), p.1426

21）小林清志，飯田嘉宏：移動論，(1991), p.102［朝倉書店］ 